\title{
Effect of saturated and unsaturated fatty acid supplementation on bio-plastic production under submerged fermentation
}

\author{
S. K. Srivastava $\cdot$ Abhishek Dutt Tripathi
}

Received: 21 September 2012/Accepted: 14 December 2012/Published online: 18 January 2013

(C) The Author(s) 2013. This article is published with open access at Springerlink.com

\begin{abstract}
Polyhydroxyalkanoates (PHAs) are intracellular reserve material stored by gram-negative bacteria under nutrient-limited condition. PHAs are utilized in biodegradable plastics (bio-plastics) synthesis due to their similarity with conventional synthetic plastic. In the present study, the effect of addition of saturated and unsaturated fatty acids (palmitic acid, stearic acid, oleic acid and linoleic acid) on the production of PHAs by the soil bacterium Alcaligenes sp. NCIM 5085 was studied. Fatty acid supplementation in basal media produced saturated and unsaturated PHAs of medium and short chain length. Gas chromatography analysis of palmitic acid-supplemented media showed the presence of short chain length (scl) PHAs which could potentially serve as precursors for bioplastic production. The scl PHA was subsequently characterized as PHB by NMR and FTIR. On the other hand, oleic acid and linoleic acid addition showed both saturated and unsaturated PHAs of different chain lengths. Palmitic acid showed maximum PHB content of $70.8 \%$ at concentration of $15 \mathrm{~g} \mathrm{l}^{-1}$ under shake flask cultivation. When shake flask cultivation was scaled up in a 7.5-1 bioreactor (working volume 3 1), $7.6 \mathrm{~g} \mathrm{l}^{-1}$ PHA was produced with a PHB yield $\left(Y_{\mathrm{P} / \mathrm{X}}\right)$ and productivity of $75.89 \%$ and $0.14 \mathrm{~g}^{-1} \mathrm{~h}$, respectively.
\end{abstract}

Keywords Polyhydroxyalkanoates (PHAs) .

Fatty acid supplementation - Bio-plastic .

Characterization

S. K. Srivastava · A. D. Tripathi $(\bowtie)$

School of Biochemical Engineering, Institute of Technology,

Banaras Hindu University, Varanasi 221005, India

e-mail: abhi_itbhu80@rediffmail.com

\section{Introduction}

Polyhydroxyalkanoates (PHAs) are polymers of hydroxyalkanoate that are synthesized and accumulated as intracellular carbon and energy storage in various microorganisms. In comparison to the conventional petroleumderived plastics, PHAs are attracting considerable attention in the plastic market due to their biodegradability under aerobic/anaerobic conditions, enormous application in the field of tissue engineering and as environment friendly packaging material (Liu et al. 2007). PHA composition is profoundly affected by the type of carbon source and the monomeric composition of PHA determines the quality of bio-plastic. Fatty acids can be used as supplements in the formation of PHA with monomers having the potential to serve as biodegradable plastics. Fatty acid $\beta$-oxidation leads to increase in the acetyl-CoA concentration which in turn shifts the TCA cycle to PHA synthesis. Hence, the present study explores the effect of fatty acids as nutritional supplement on PHA production by an Alcaligenes sp. Oleic and lauric acid have been extensively used as nutritional supplements for PHA production in Aeromonas hydrophila (Chen et al. 2001), Ralstonia eutropha (Marangoni et al. 2000), recombinant Escherichia coli XY1-Blue pSYL105 (Lee et al. 1995). Certain vegetable oil supplementation in basal media enhanced exopolysaccharide production (Bolla et al. 2011; Park et al. 2001). It has also been shown that plant and vegetable oil produce a stimulatory effect on the production of polysaccharides (Yang et al. 2000; Huisman et al. 1989), mcl PHA synthesis (Gustavo and Regina 2006).

In the present research, efforts have been made to study the effects of saturated and unsaturated fatty acid supplementation on biodegradable plastic production by the soil bacterium Alcaligenes sp. in a submerged fermentation process. In addition, the effect of these additives on PHA content 
was also investigated. Optimization of fatty acid concentration for enhanced PHA production was also performed. PHA produced in shake flask cultivation was scaled up in a bioreactor. The characterization of PHA was performed by Fourier transform infrared spectroscopy (FTIR) and NMR.

\section{Materials and methods}

Bacterial strain

Alcaligenes sp. NCIM No. 5085 was obtained from National Chemical Laboratory (NCL), Pune, India.

Growth and production media

The growth medium, mineral salt medium (MSM), contained $\left(\mathrm{g} \mathrm{l}^{-1}\right)$ : fructose 10 , urea $0.8, \mathrm{KH}_{2} \mathrm{PO}_{4} 2.0, \mathrm{Na}_{2} \mathrm{HPO}_{4}$ $0.6, \mathrm{MgSO}_{4} \cdot 7 \mathrm{H}_{2} \mathrm{O} 1.0$, yeast extract 0.1 and $1 \mathrm{ml} \mathrm{l}^{-1}$ of trace element $\left[\mathrm{ZnSO}_{4} \cdot 7 \mathrm{H}_{2} \mathrm{O} 1.3, \mathrm{CaCl}_{2} 20.0, \mathrm{FeSO}_{4} \cdot 7 \mathrm{H}_{2} \mathrm{O}\right.$ $0.2,\left(\mathrm{NH}_{4}\right)_{6} \mathrm{Mo}_{7} \mathrm{O}_{24} \cdot 4 \mathrm{H}_{2} \mathrm{O} 0.6$ and $\mathrm{H}_{3} \mathrm{BO}_{3}$ 0.6]. Fructose was sterilized separately at $121{ }^{\circ} \mathrm{C}$ for $15 \mathrm{~min}$ and added aseptically into the flask containing the other components at room temperature. The $\mathrm{pH}$ of the final culture medium was adjusted to $7 \pm 0.5$ with $0.1 \mathrm{~N} \mathrm{HCl}$ or $0.1 \mathrm{~N} \mathrm{NaOH}$ prior to inoculation. Production media was prepared in $250 \mathrm{ml}$ conical flask containing $100 \mathrm{ml}$ MSM. Composition of production media was same as growth media, except that fructose concentration in production media was $40 \mathrm{~g}^{-1}$. Five $\mathrm{ml}$ of the seed of each bacterial strain inoculum was added into different conical flasks containing $100 \mathrm{ml}$ of production medium and incubated at $150 \mathrm{rpm}, 37^{\circ} \mathrm{C}$ for $48 \mathrm{~h}$. Samples were extracted for PHA analysis at different time intervals, viz, 12, 24, 36, 48 and $72 \mathrm{~h}$, respectively.

Fatty acid supplementation

Four types of fatty acids: palmitic acid (16:0), stearic acid (18:0), oleic acid (18:1) and linoleic acid (18:2) were used as nutritional supplements at a concentration of $5 \mathrm{~g} \mathrm{l}^{-1}$ for studying PHA production. All the experiments were performed in triplicates.

\section{Analytical study}

Dry cell mass

Broth culture of $20 \mathrm{ml}$ was centrifuged at $10,000 \mathrm{rpm}$ for 10 min at $4{ }^{\circ} \mathrm{C}$, the cell pellet washed with saline water $\left(\mathrm{NaCl} 0.8 \%\right.$, wt $\left.\mathrm{vol}^{-1}\right)$ and dried in aluminium weighing dishes at $90{ }^{\circ} \mathrm{C}$ for $24 \mathrm{~h}$. This dry cell mass was further used for PHA extraction and estimation.

\section{PHA extraction}

PHA was extracted using chloroform-hypochlorite extraction method. Pure PHA was obtained by non-solvent precipitation (five times the volume of chloroform) and filtration. The non-solvent used was a mixture of methanol and water $\left(7: 3, \mathrm{vol} \mathrm{vol}^{-1}\right)$. Filtration was performed using membrane filters ( $2 \mu \mathrm{m}$, Millipore).

PHA estimation

Samples for GC analysis were prepared as described by Braunegg et al. (1978). Analysis was performed in a GC (Shimadzu, Model: QP-5000) equipped with a flame ionization detector (FID) with a split less injection (80:1) using a DB wax column (polar, $30 \mathrm{~m}, 0.32 \mu \mathrm{m}, 0.25 \mu \mathrm{m}$ thickness). The carrier gas used was nitrogen at flow rate of $10 \mathrm{ml} \mathrm{min}{ }^{-1}$, the injector temperature was maintained at $250{ }^{\circ} \mathrm{C}$, the oven temperature was set at $50{ }^{\circ} \mathrm{C}$ which was increased to $200{ }^{\circ} \mathrm{C}$ at the rate of $15^{\circ} \mathrm{C} \mathrm{min}{ }^{-1}$ for $30 \mathrm{~min}$. Benzoic acid was used as internal standard.

\section{FTIR and NMR analysis}

Sample preparation for Fourier transform infrared spectroscopy (FTIR) was performed in a Bruker model IFS-55 FTIR spectrometer coupled to a Bruker IR microscope fitted with an IBM compatible PC running OPUS, Version 2.2 software (Tripathi and Srivastava 2011). ${ }^{1} \mathrm{H}$ NMR spectra was obtained at $500 \mathrm{~Hz}$ with Bruker Advance 500 in chloroform-d at $45{ }^{\circ} \mathrm{C}$.

\section{Results and discussion}

Effect of saturated fatty acid supplementation on PHA composition

Effect of fatty acid supplementation on PHA yield and its composition were studied by collecting $10 \mathrm{ml}$ of samples from different trials after $60.0 \mathrm{~h}$ of cultivation. PHA recovered from bacterial strain under different cultivation conditions was analyzed by GC. Gas chromatogram of PHA extracted from Alcaligenes sp. grown on MSM after $60.0 \mathrm{~h}$ of cultivation showed short chain length ( $\mathrm{scl}$ ) and medium chain length (mcl) PHAs, viz, 3-hydroxybutyrate (3HB); 3-hydroxydocanoate (3HD); 3-hydroxy 9 carbon saturated alkanoate (C9:0) and 3-hydroxy 12 carbon saturated alkanoate (C12:0) with retention time (RT) of 7.60, 12.83, 17.16 and $21.25 \mathrm{~min}$, respectively (Fig. 1a). Table 1 depicts the effect of fatty acid supplementation on monomer composition of PHA. PHA produced on MSM 

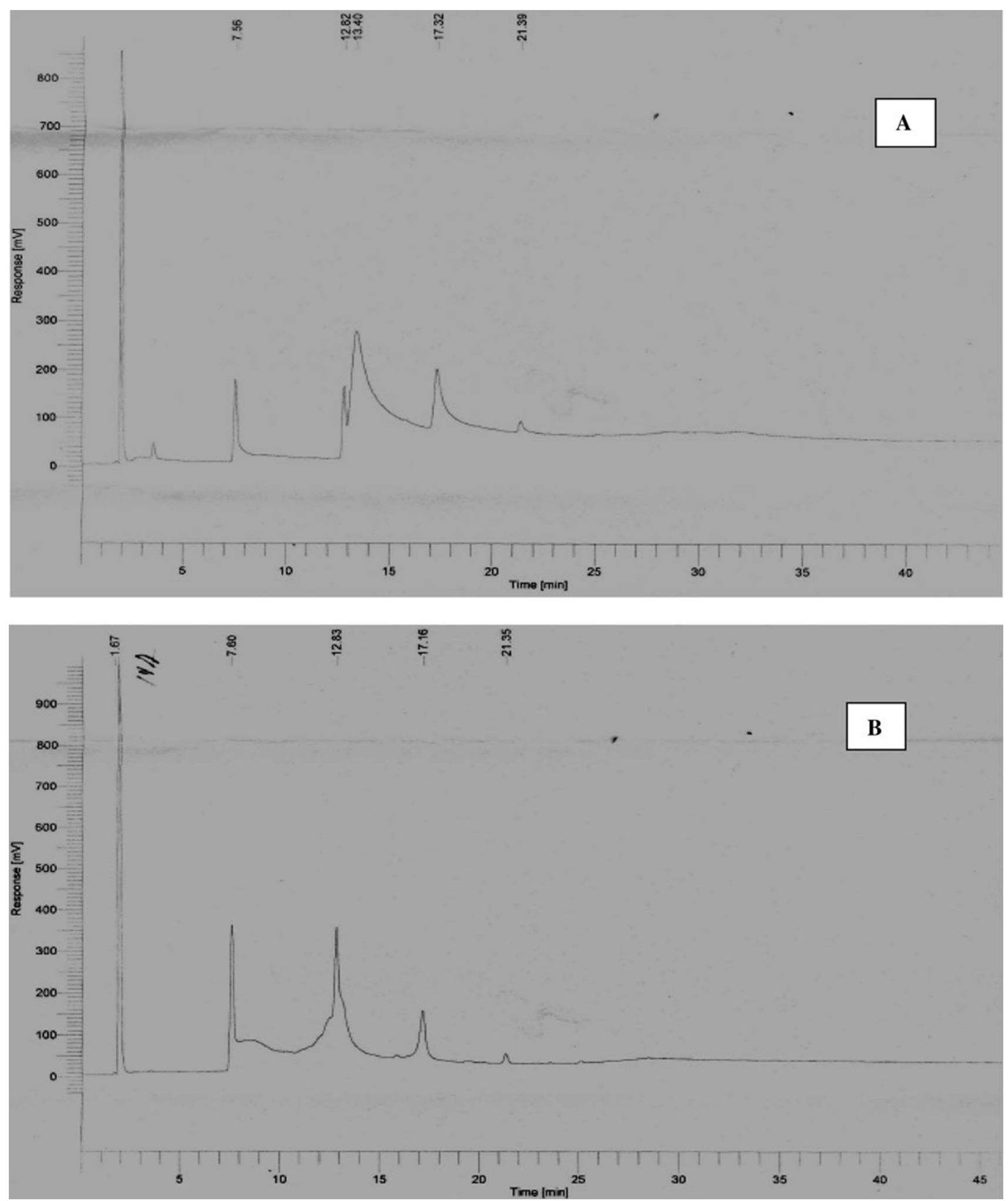

Fig. 1 Gas chromatography (GC) analysis of PHA extracted from Alcaligenes sp. on basal media for PHA production in shake flask cultivation a non-supplemented media, b palmitic acid $\left(5.0 \mathrm{~g} \mathrm{l}^{-1}\right)$ -

supplemented media, c oleic acid $\left(5.0 \mathrm{~g} \mathrm{l}^{-1}\right)$-supplemented media and $\mathbf{d}$ linoleic acid $\left(5.0 \mathrm{~g}^{-1}\right)$-supplemented media 

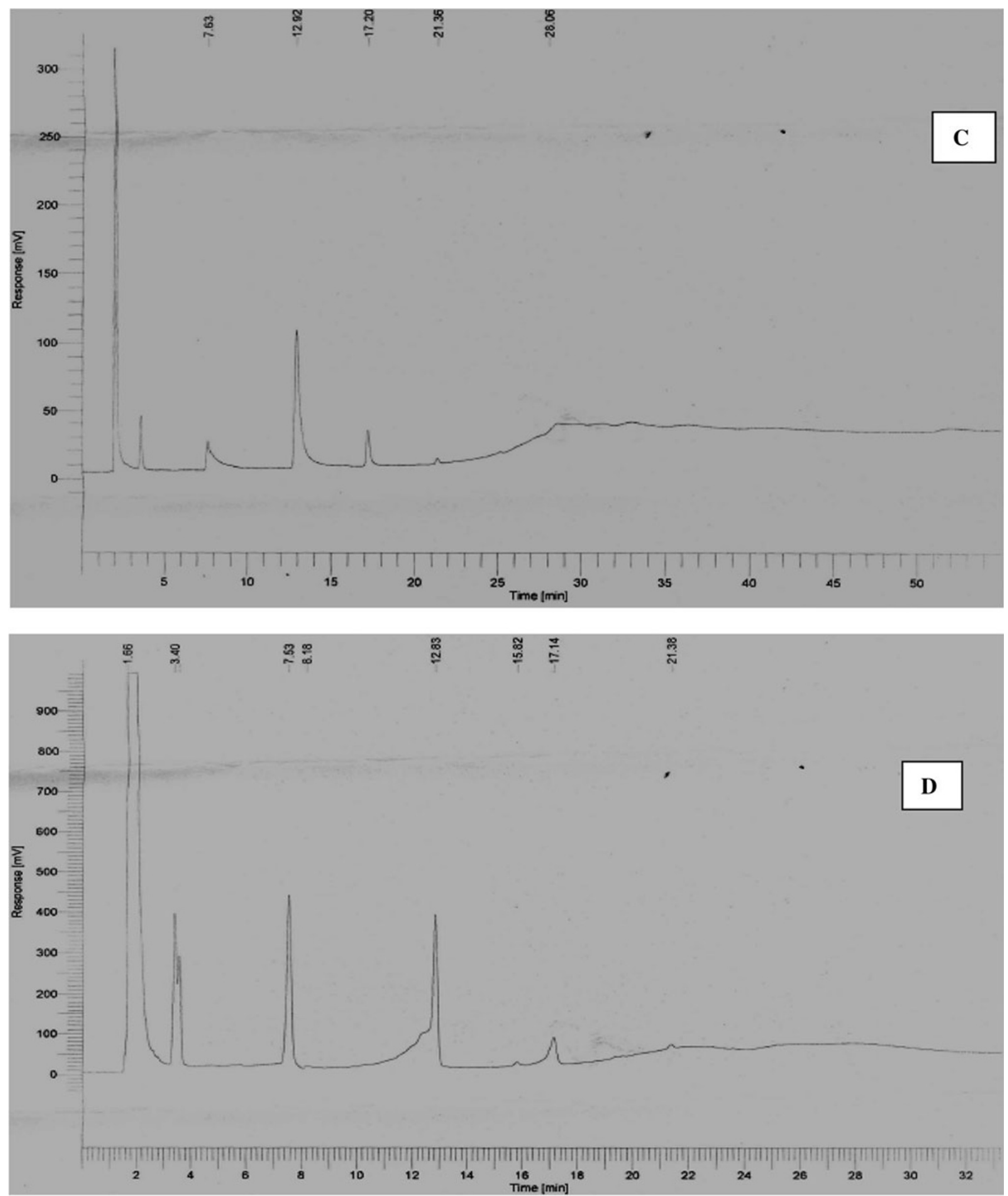

Fig. 1 continued

containing fructose as sole carbon source constituted $56.80 \% 3 \mathrm{HB}, 36.10 \%$ 3-hydroxydodocanoate (3HDD), $5.60 \% 3-\mathrm{OH}$ saturated alkanoate (9:0) and $1.0 \% 3-\mathrm{OH}$ saturated alkanoate (12:0). Trace amount $(<0.5 \mathrm{~mol} \%$ PHA) of $3 \mathrm{HV}$ was also produced from Alcaligenes sp. grown on MSM. 


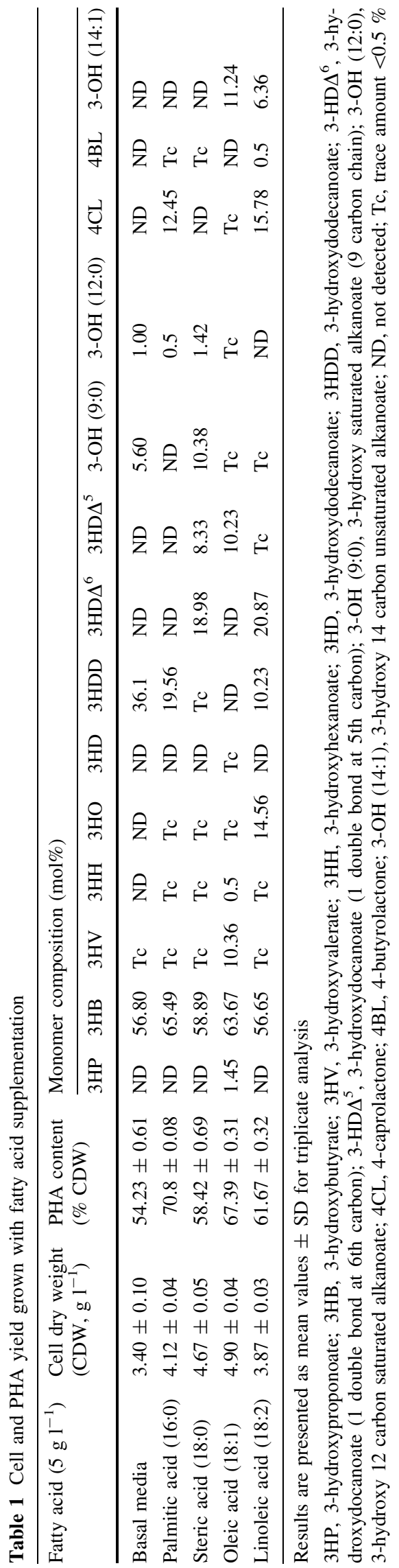

Palmitic acid (16:0) incorporation in basal MSM gave scl PHA including PHB and mcl PHAs consisting of 3HD, 4-caprolactone (4CL, RT $17.19 \mathrm{~min}$ ), 12 carbon 3-hydroxyalkanoate (RT $21.35 \mathrm{~min}$ ) and 14 carbon 3-hydroxyalkanoate (RT $28.06 \mathrm{~min}$ ) (Fig. 1b). Palmitic acid addition in MSM enhanced PHA yield from $54.23 \pm 0.61$ to $70.8 \pm 0.08 \%$, which is in correlation with a previous finding (Lo et al. 2005). 3HB constituted $65.49 \%$ of PHA (\% mol) in palmitic acid-supplemented media. MCL PHAs, 3HDD and 4CL also constituted PHA which is in conformity with a previous finding (Eggink et al. 1990; Huisman et al. 1989). Formation of different monomers on the same substrate indicates that a common intermediate of fatty acid metabolism serves as precursor in the synthesis of PHA monomers. Acetyl-CoA is a likely candidate for this because of its central role in the carbohydrate metabolism.

Gas chromatogram (GC) of stearic acid-supplemented media produced scl and mcl PHAs, viz., 3HB, 3HD $\Delta^{6}$, $3 \mathrm{HD} \Delta^{5}, 3-\mathrm{OH}(9: 0)$ and $3-\mathrm{OH}(12: 0)$ saturated alkanoate (figure not shown). The monomers $3 \mathrm{HD} \Delta^{5}$ and $3 \mathrm{HD} \Delta^{6}$ exactly match the acyl moieties of 3-hydroxy-acyl carrier protein intermediates of the unsaturated fatty acid biosynthetic pathway. Stearic acid (18:0) addition in MSM increased cell mass from 3.40 to $4.67 \mathrm{~g}^{-1}$. However, PHA content was lesser in comparison to PHA content observed in MSM supplemented with palmitic acid. This may be attributed to higher specificity of PHA synthase toward palmitic acid breakdown intermediates in comparison to stearic acid.

PHA produced on MSM supplemented with stearic acid comprised $3 \mathrm{HB}, 3 \mathrm{HD} \Delta^{6}, 3 \mathrm{HD} \Delta^{5}$ and $3-\mathrm{OH}(9: 0)$ saturated alkanoate at molar composition of 58.89, 18.98, 8.33 and $10.38 \%$, respectively (Table 1 ).

Effect of unsaturated fatty acid supplementation on PHA composition

Oleic acid (18:1) and linoleic acid (18:2) addition in MSM for PHA production increased mcl saturated and unsaturated hydroxyalkanoates (Fig. 1c, d). It can be clearly elucidated from Fig. 1c that oleic acid addition in PHA cultivation media produced 3-hydroxyvalerate (3HV) and $3 \mathrm{HD} \Delta^{5}$ along with $3 \mathrm{HB}$. Monomeric composition of PHA showed that it contained $63.67 \% 3 \mathrm{HB}, 11.24 \% 3-\mathrm{OH}$ (14:1) unsaturated alkanoate, $10.36 \% 3 \mathrm{HV}$ and $10.23 \%$ $3 \mathrm{HD}^{5}$ (Table 1) which is similar to a previous finding (Braungg 1994). Alcaligenes sp. showed higher PHA yield under similar condition in comparison to a previous report (Satish et al. 2011) due to enhanced PHA synthase and reduced depolymerase activity. PHAs formed from euphorbia oil comprised similar monomers generated via $\beta$-oxidation of vernolic acid $(\delta 12,13$-epoxy-9c-octadecenoic acid), the main component of euphorbia oil (Eggink et al. 1995). 
Linoleic acid (18:2)-supplemented basal media produced $61.67 \pm 0.32 \%$ PHA with 3 HB content of $56.65 \%$ (\% mol PHA). Linoleic acid addition in MSM gave wide range of mcl saturated, ringed and unsaturated hydroxyalkanoates having 6-20 carbon chain length, viz, 3HO, $3 \mathrm{HDD}, 3 \mathrm{HD} \Delta^{6}$, 4CL, 4-butyrolactone and 3-OH (14:1) unsaturated alkanoate. $3 \mathrm{HDD}$ and $3 \mathrm{HD} \Delta^{6}$ monomers are produced via three cycles of $\beta$-oxidation. The synthesis of both saturated and unsaturated PHA monomers by linoleic acid addition in MSM may be attributed to generation of sequential intermediates in the fatty acid metabolic pathway of bacteria suggesting a possible linkage between de novo fatty acid oxidation and PHA synthesis (Slater et al. 1988).

Oleic acid and linoleic acid showed pronounced effect on cell mass. Oleic acid supplementation enhanced cell mass; however, linoleic acid addition showed lesser cell mass in comparison to non-fatty acid-supplemented MSM (Table 1). This may be attributed to the presence of two double bonds in linoleic acid which suppressed the cell growth. The monomers $3 \mathrm{HD} \Delta^{5}$ and $3 \mathrm{HD} \Delta^{6}$ exactly match the acyl moieties of 3-hydroxyacyl-acyl carrier protein intermediates of the unsaturated fatty acid biosynthetic pathway. Previously, Pseudomonas putida grown in oleic acid- and linoleic acid-supplemented medium showed similar PHA monomers which are formed though a common intermediate 3-hydroxyacyl-CoAs, derived from the dienoyl-CoA reductase pathway (Tan et al. 1997).

Palmitic acid increased PHA content (\% CDW) and dry cell mass in comparison to stearic acid and unsaturated fatty acids (oleic and linoleic acid) which is in correlation with a previous finding of Lo et al. (2005), who reported that saturated fatty acid (palmitic acid and stearic acid) promoted cell growth in $S$. natans. $3 \mathrm{HB}$ content was highest in palmitic acid added media in comparison to oleic acid- and linoleic acid-supplemented medium. This may be attributed to decreased NADH-dependent 2,4-dienoyl-CoA reductase activity which reduces $\Delta^{4}$ double bond in linoleic acid oxidation pathway (Table 1).
Effect of palmitic acid concentration on PHA composition

Effect of palmitic acid concentration on PHA content in Alcaligenes sp. was studied at different concentrations, viz, 5, 10, 15, 20 and $25 \mathrm{~g} \mathrm{l}^{-1}$ (Table 2). Maximum PHA concentration of $74.80 \pm 0.34 \%(\mathrm{CDW})$ with maximum 3HB content of $70.89 \%$ was obtained in $15 \mathrm{~g} \mathrm{l}^{-1}$ palmitic acid-supplemented medium. Further increase in fatty acid concentration enhanced mcl PHA but $3 \mathrm{HB}$ concentration was decreased.

\section{Scale up in 7.51 bioreactor}

Shake flask study was then scaled up to a lab-scale bioreactor. The culture was grown in a 7.5-1 bentchtop bioreactor (BioFlo/Celligen 115, New Brunswick, USA) to study PHA production in batch cultivation. Working volume of bioreactor was kept at 3.0 1. Batch cultivation study was carried out to understand the kinetics of PHB production under controlled condition of temperature, $\mathrm{pH}$, agitation and aeration. Figure 2 represents the time profile of PHA synthesis on $15 \mathrm{~g} \mathrm{l}^{-1}$ palmitic acid-supplemented medium. Fructose and urea served as carbon and nitrogen sources at initial concentrations of 40.0 and $0.8 \mathrm{~g} \mathrm{l}^{-1}$, respectively. $\mathrm{pH}$ was kept at $7.00 \pm 0.5$ throughout the production process and DO was maintained at $30 \%$ saturation value with an agitation speed of $350 \mathrm{rpm}$. Agitation speed and DO cascade were done by setting minimum and maximum agitation speed at 100 and $400 \mathrm{rpm}$, respectively, to maintain the desired dissolved oxygen concentration. Aeration rate during PHB production was kept at $1.51 \mathrm{~min}^{-1}$ and cultivation temperature was set at $37^{\circ} \mathrm{C}$. Figure 2 clearly depicts that after a lag phase of $12.0 \mathrm{~h}$, biomass increased to $9.80 \mathrm{~g} \mathrm{l}^{-1}$ at $54.0 \mathrm{~h}$. Maximum PHA production was found to be $7.62 \mathrm{~g} \mathrm{l}^{-1}$ after $54.0 \mathrm{~h}$ of fermentative production. Total sugar concentration decreased to $1.6 \mathrm{~g} \mathrm{l}^{-1}$ at the end of production phase in comparison to initial concentration of $40.0 \mathrm{~g} \mathrm{l}^{-1}$. Nitrogen source also depleted after $24.0 \mathrm{~h}$ of

Table 2 Cell and PHA yield grown with palmitic acid supplementation

\begin{tabular}{|c|c|c|c|c|c|c|}
\hline \multirow{2}{*}{$\begin{array}{l}\text { Palmitic acid } \\
\text { concentration }\left(\mathrm{g} \mathrm{l}^{-1}\right)\end{array}$} & \multirow{2}{*}{$\begin{array}{l}\text { Cell dry weight } \\
\left(\mathrm{CDW}, \mathrm{g}^{-1}\right)\end{array}$} & \multirow{2}{*}{$\begin{array}{l}\text { PHA content } \\
(\% \mathrm{CDW})\end{array}$} & \multicolumn{4}{|c|}{ Monomer composition (mol\%) } \\
\hline & & & HB & HDD & 3-OH (12:0) & $4 \mathrm{CL}$ \\
\hline 5.0 & $4.12 \pm 0.04$ & $54.23 \pm 0.55$ & 65.49 & 20.56 & 0.5 & 13.45 \\
\hline 10.0 & $4.56 \pm 0.11$ & $58.42 \pm 0.42$ & 67.25 & 17.56 & 0.5 & 14.69 \\
\hline 15.0 & $5.5 \pm 0.16$ & $74.80 \pm 0.34$ & 70.89 & 13.5 & 0.7 & 14.91 \\
\hline 20.0 & $6.1 \pm 0.06$ & $67.39 \pm 0.43$ & 62.76 & 18.78 & 2.3 & 16.66 \\
\hline 25.0 & $6.7 \pm 0.13$ & $61.67 \pm 0.34$ & 58.98 & 24.18 & 1.8 & 14.04 \\
\hline
\end{tabular}

Results are presented as mean values \pm SD for triplicate analysis

HB, Hydroxybutyrate; HDD, hydroxydodecanoate; 3-OH (12:0), 3-hydroxy 12 carbon saturated alkanoate; 4CL, 4-caprolactone 
Fig. 2 Time profile of PHA and cell mass production, fructose and urea utilization in $7.51 \mathrm{New}$ Brunswick Bioflo Fermentor (working volume 3.0 l)

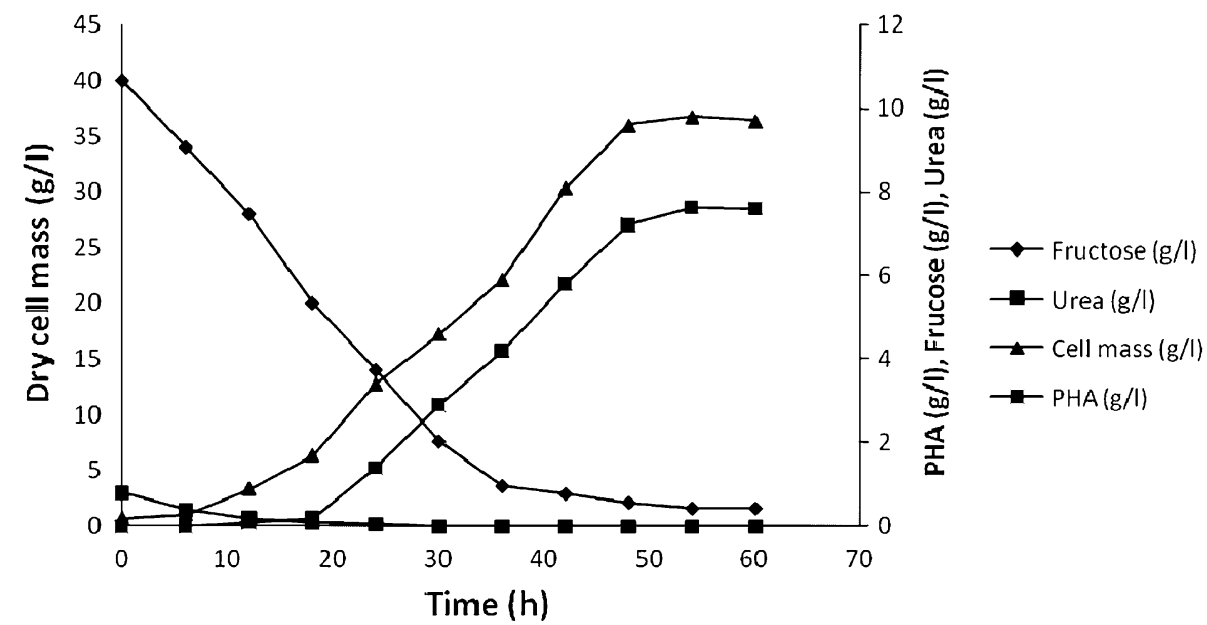

Fig. 3 FTIR analysis of PHA extracted from Alcaligenes sp. on palmitic acid-supplemented $\left(16 \mathrm{~g}^{-1}\right)$ in basal media for PHA production under optimized cultivation condition

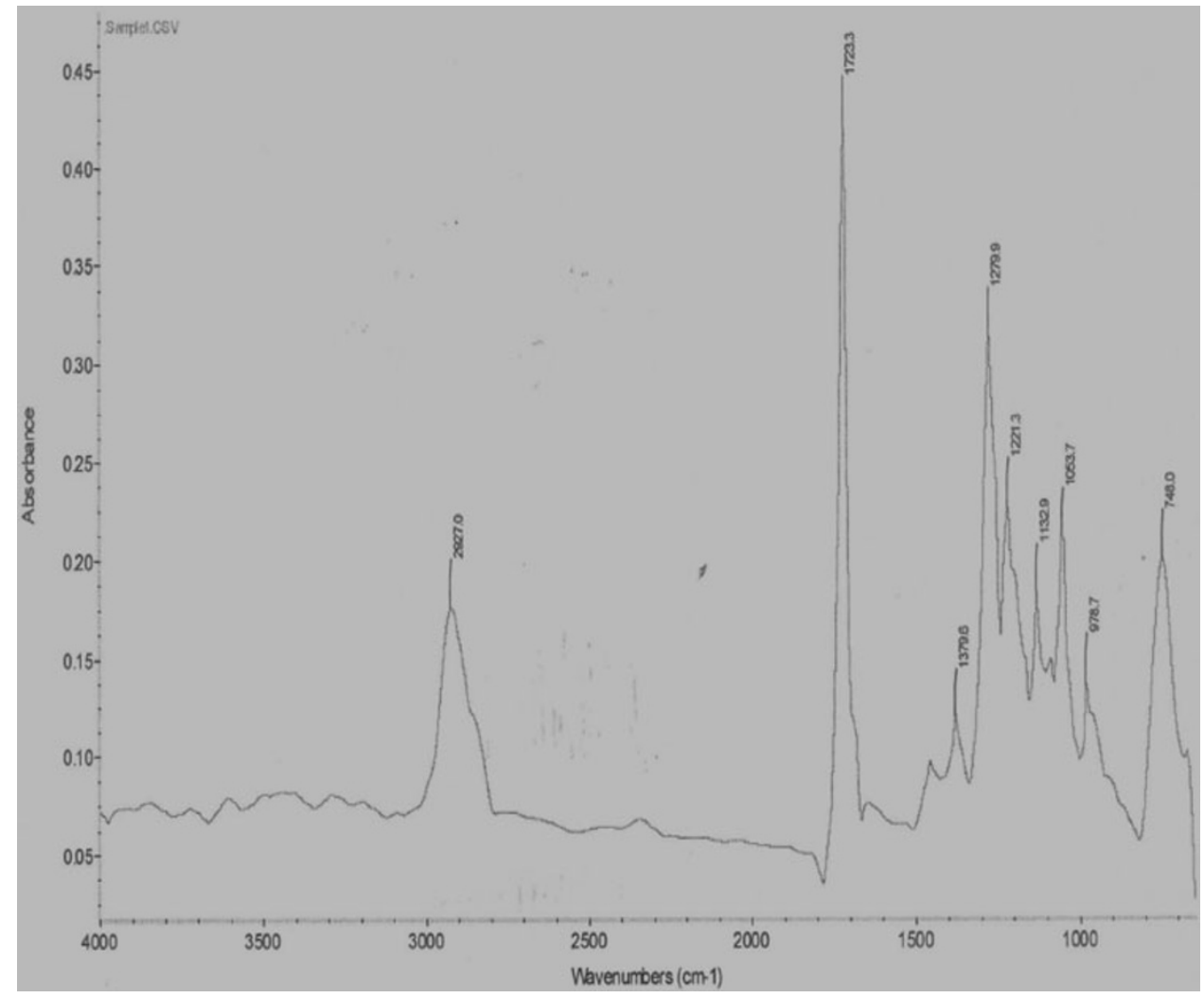

cultivation which leads to enhanced PHB production. PHA yield $\left(Y_{\mathrm{P} / \mathrm{X}}\right)$ in terms of cell biomass produced and substrate consumed were found to be 0.78 ( $\mathrm{g} \mathrm{g}^{-1}$ cell mass) and 0.27 ( $\mathrm{g} \mathrm{g}^{-1}$ substrate consumed). Percentage PHA yield ( $\left.Y_{\mathrm{P} / \mathrm{X}}\right)$ of $78.0 \%$ obtained in the present study is higher than previously reported yield (Tripathi and Srivastava 2011). PHA obtained after scale up on 7.51 bioreactor comprised $75.89 \%$ HB, $12.34 \%$ HDD, $1.1 \%$ 3-OH (12:0) alkanoate and $10.67 \%$ 4CL. Fed batch cultivation of $P$. putida in 3.01 bioreactor using oleic acid and nitrogen source produced
$44.0 \%$ (\% DCW) PHA with \% yield of 0.10 (g PHA/g carbon) (Marsudi et al. 2007).

\section{Characterization of PHA by FTIR and NMR}

FTIR was used for the evaluation of chemical structure of PHA (Fig. 3). FTIR spectra predicted the presence of functional groups of $\mathrm{PHB}$, i.e., aliphatic $\mathrm{C}-\mathrm{H},=\mathrm{O}$ stretching, $=\mathrm{C}-\mathrm{H}$ deformation, $=\mathrm{C}-\mathrm{H},=\mathrm{CH},=\mathrm{C}-\mathrm{O}$, etc. (Nur et al. 2004). Figure 3 represented a sharp peak at wave number 
Fig. $4{ }^{1} \mathrm{H}-\mathrm{NMR}\left(\mathrm{D}_{2} \mathrm{O}\right)$ of polyhydroxyalkanoate extracted from Alcaligenes sp. in palmitic acid-supplemented media

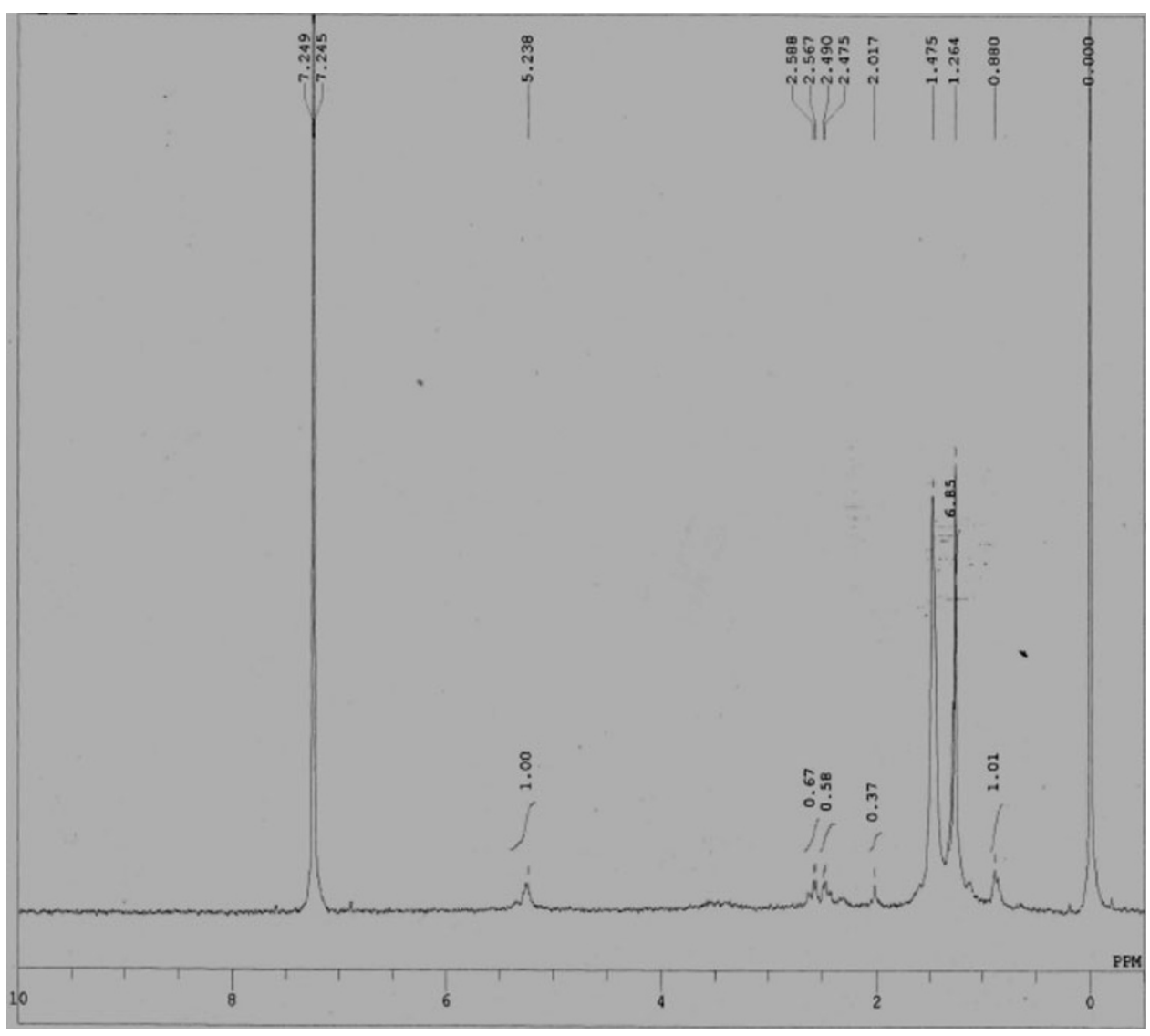

further genetic and enzymatic studies are needed to elucidate the relationship between fatty acid metabolism and PHA biosynthesis.

Acknowledgments We would like to pay our sincere thanks to Dr. S.B. Roy for providing us FT-IR facility at Department of Physics, Banaras Hindu University, Varanasi 221005, UP, India. We are also grateful to Sophisticated Analytical Instrumentation Facility (SAIF) Central Drug Research Institute, Lucknow and Department of Chemistry, Banaras Hindu University, Varanasi 221005, UP, India for providing us GC and NMR facility.

Conflict of interest The authors declare that they have no conflict of interest.

Open Access This article is distributed under the terms of the Creative Commons Attribution License which permits any use, distribution, and reproduction in any medium, provided the original author(s) and the source are credited.

\section{References}

Bolla K, Hima SVSSL, Bindu N, Samatha B, Singara Charya MA (2011) Effect of plant oils, surfactants and organic acids on the production of mycelial biomass and exopolysaccharides of Trametes spp. J Agric Technol 7:957-965

Braunegg G, Sonnleitner B, Lafferty RM (1978) A rapid gas chromatographic method for the determination of poly- $\beta$ hydroxybutyric acid in microbial biomass. Eur J Appl Microbiol Biotechnol 6:29-37 
Braungg G (1994) Gas chromatographic analysis of polyhydroxyalkanoates in bacteria. Biotechnol Tech 8(3):187-192

Chen GQ, Zhang G, Park SJ, Lee SY (2001) Industrial production of poly(hydroxybutyrate-co-hydroxyhexanoate). Appl Microbiol Biotechnol 57:50-55

Eggink G, Van der Wal H, Huberts GNM (1990) Production of poly3-hydroxyalkanoates by $P$. putida during growth on long-chain fatty acids. In: Dawes EA (ed) Novel biodegradable microbial polymers. NATO ASI Series. Kluwer, Dordrecht

Eggink G, Waard D, Huijberts P (1995) Formation of novel poly(hydroxyalkanoates) from long chin fatty acids. Can J Microbiol 41:14-21

Gustavo GF, Regina VA (2006) Use of vegetable oils as substrates for medium-chain-length polyhydroxyalkanoates production by recombinant Escherichia coli. Biotechnol 5(3):277-279

Huisman GW, De Leeuw O, Eggink G, Witholt B (1989) Synthesis of poly-3-hydroxyalkanoates is a common feature of fluorescent pseudomonads. Appl Environ Microbiol 55:1949-1954

Lee SY, Kang SH, Choi CY (1995) Poly(hydroxybutyrate-cohydroxyvalerate) from glucose and valerate in Alcaligenes eutrophus. J Ferment Bioeng 79:328-334

Liu Q, Ouyang SP, Chung A, Wu Q, Chen GQ (2007) Microbial production of R-3-hydroxybutyric acid by recombinant $E$. coli harboring genes of phbA, phbB, and tesB. Appl Microbiol Biotechnol 76:811-818

Lo KW, Chua H, Lawford H, Lo WH, Peter H, Yu F (2005) Effects of fatty acids on growth and poly-3-hydroxybutyrate production in bacteria. Appl Biochem Biotechnol 121:575-580

Marangoni C, Furigo AJR, de Aragao GMF (2000) Oleic acid improves poly(3-hydroxybutyrate-co-3-hydroxyvalerate) production by Ralstonia eutropha in inverted sugar and propionic acid. Biotechnol Lett 22:1635-1638

Marsudi S, Tan IKP, Gan S-N, Ramachandran KB (2007) Production of medium chain length polyhydroxyalkanoates from oleic acid using Pseudomonas putida pga1 by fed batch culture. Makara Technol 11:1-4

Nur ZY, Belma A, Yavuz B, Nazime M (2004) Effect of carbon and nitrogen sources and incubation time on poly-beta-hydroxybutyrate (PHB) synthesis by Bacillus megaterium 12. Afr J Biotechnol 3:63-69

Park JP, Kim SW, Hwang HJ, Yun JW (2001) Optimization of submerged culture conditions for the mycelial growth and exobiopolymer production by Cordyceps militaris. Lett Appl Microbiol 33:76-81

Reddy VS, Thirumala M, Mahmood M (2010) Production and characterization of PHB from two novel strains of Bacillus sp. isolated from soil and activated sludge. J Ind Microbiol Technol 37:271-278

Satish M, Anbuselvi S, Vikram M, Soujanya M (2011) Biosynthesis and characterization of biodegradable plastics from Pseudomonas oleovorans and Alcaligenes eutrophus. Int J Adv Biotechnol Res 2(3):329-333

Slater SC, Voige WH, Dennis DE (1988) Cloning and expression in Escherichia coli of the Alcaligenes eutrophus H16 poly$p$-hydroxybutyrate biosynthetic pathway. J Bacteriol 170: 431-436

Tan IKP, Sudesh Kumar K, Theanmalar M, Gan SN, Gordon B (1997) Saponified palm kernel oil and its major free fatty acids as carbon substrates for the production of polyhydroxyalkanoates in Pseudomonas putida PGA1. Appl Microbiol Biotechnol 47(3):207-211

Tripathi AD, Srivastava SK (2011) Kinetic study of biopolymer (PHB) synthesis in Alcaligenes sp. in submerged fermentation process using TEM. J Polym Sci Environ 19:732-738

Yang FC, Ke YF, Kuo SS (2000) Effect of fatty acids on the mycelia growth and polysaccharide formation by Ganoderma lucidum in shake flask cultures. Enzyme Microbiol Technol 27:295-301 